preferably be of middle supervisory grade in an organization or government department working for village improvement. Candidates for scholarships should be younger persons, of graduate status, who already have an interest in working for village improvement and propose to embark on this as a career. Candidates for scholarships need not have experience of community development.

Fellows and scholars will work under the Director of Social Welfare and Community Development and officers of the Department nominated by him to supervise them. Short periods of lectures, visits, and other special training will be included in the programme. A report on each scholar and fellow will be made to the nominating government at the end of the period of training.

Nomination forms may be obtained from FAMA, 2-8 Victoria Street, London, S.W.I. Nominations should reach London by ro March 1960 , and the awards will be made and notified to governments as soon as possible after that date.

\title{
The 1959 Training Courses in Community Development Provided by the Government of Ghana
}

THE I959 courses, under the auspices of FAMA, started on 4 May. The recipients of the awards came from Angola, Ethiopia, the Ivory Coast, Republic of Togoland (2), and Sierra Leone. The first week of training was taken up with lectures at the headquarters in Accra of the Department of Social Wclfare and Community Development, a film show, and visits to centres of interest in Accra such as the Accelerated Artisan Training Scheme and the Bureau of Ghana Languages. The lectures given by the Director and other senior members of the department covered many aspects of community development, including mass education, techniques of literacy work and demonstration, self-help construction work, techniques in village building, visual aids, and extension work in community development. The next three weeks were occupied with visits, of one week each, to the Western, Ashanti, and Northern Regions of Ghana. The scholars and fellows then returned to Accra to participate in a one-day seminar held at the University College of Ghana. After this they divided up and were posted to four regions to work with the departmental staff in the region. Each was required to keep a daily diary and to record his itineraries. The training was completed in October with a brief period of discussion at departmental headquarters in Accra.

\section{Three Unknown Logbooks of Ibn Majid, the Arab pilot of Vasco da Gama}

Thrs is the first printed edition of three logbooks of Ibn Majid from the manuscript in the possession of the Leningrad Institute of Oriental Studies. The books contains a Russian metric translation of the logs (pp. I 3-57), a facsimile of the Arabic manuscript (44 pages of text), an historical introduction and comparative study of the two Ibn Majid manuscripts in the Bibliothèque Nationale, a palaeographic description (pp. 63-ro4), notes, and annexes consisting of a topographical index, map of the Indian Ocean, astronomical index, the Arab rose of winds, moon phases, glossary of Arabic navigational terms, and a metric and thyme analysis.

Shumovsky dates the manuscript as $1500 / 1501$, thus making it the latest known Ibn Majid record. The manuscript was first listed in the catalogue of the Asiatic Museum of St. Petersburg in I8I9, a year after its foundation. This catalogue was compiled by its first director, Academician Fraehn (Codicum Manuscriptorum arabicorum, persicorum et turcicorum, qui in Academiae Imperialis Scientiarum Museo Asiatico asservantur.)

\section{[Communicated by M. H.]}

In the unique manuscript at the Institute of Oriental Studies of the U.S.S.R. Academy of Sciences. Translated and edited by T. A. Shumovsky with an introduction by Professor D. A. Olderogge; published by the U.S.S.R. Academy of Sciences, MoscowLeningrad, 1957. Pp. 195, maps and diagrams, biblio. 